\title{
Ballerinas and Band Aids: The Performances of Urban Art in Post-Earthquake Christchurch
}

Reuben Woods

Keywords: \# Graffiti \# Street Art \# Christchurch earthquake \# visual arts \# large-scale murals \# memorialisation \# contemporary muralism

While graffiti and street art span generations and all corners of the globe, it was still unexpected when Christchurch, a New Zealand city identified by many as a colonial English transplant with a perceived conservative air, was positioned as an urban art 'destination' in the wake of the devastating cluster of earthquakes in 2010 and 2011.' Historically lacking a strong sense of street culture, such as that in New Orleans (which suffered similar devastation after Hurricane Katrina, 2005), Christchurch's post-quake landscape encouraged public discourses and as such required new approaches to shared space. ${ }^{2}$ As public expressions with do-it-yourself qualities already predisposed to make use of the post-quake landscape, graffiti and street art proved fitting additions to this terrain. They signified life and rebirth, while also engaging with loss and change, revealing the structures of urban and suburban existence, and creating political discourses. 
The terms 'graffiti' and 'street art' are increasingly difficult to define due to the growing complexities of diverse incarnations and approaches, as acknowledged by Rafael Schacter, Anna Waclawek and Cedar Lewisohn. ${ }^{3}$ Here, drawing on the influence of such writers, graffiti refers to the signature-based writing culture emerging from Philadelphia and New York in the 1960s, while street art suggests the diverse practices of independent art-making in public space occurring since the 1970s, but popularised post-millennium, at times referred to as post-graffiti, a reference to the formative influence of, and divergence from, the writing culture. ${ }^{4}$ While maintaining this distinction, the umbrella term urban art is also applied in recognition of its ability to capture the shared influence and broad spectrum of practices. ${ }^{5}$ Utilising the growing field of urban art scholarship and a first-hand experience of graffiti and street art in post-quake Christchurch, from the uninvited to the commissioned, tiny interventions to massive murals, explicit quake references to open-ended readings, this article suggests how the rise of urban art in Christchurch has served to highlight the way these increasingly complex and globally ubiquitous tactics are able to reveal and explore the unique characteristics of an environment. ${ }^{6}$

\section{AN UNEXPECTED SETTING}

Cities such as New York, London, Berlin, Buenos Aires and Melbourne are entrenched as meccas of urban art, due to historical and cultural significance, population density and socio-spatial qualities. However, increasingly diverse locations have also emerged; Stavanger, a

Norwegian township, Hawai'i and Tahiti all host well-known street art festivals, and intriguing examples of graffiti and street art have emerged in locations such as Egypt, Iran, Palestine and Athens in response to socio-political situations. ${ }^{7}$ While these destinations reveal interesting and relevant juxtapositions between art and setting, the organic and sprawling nature of urban art's emergence in response to the specific issues facing post-quake Christchurch provides a unique insight into the multi-layered and transferable performances of a global phenomenon.

Pre-quake Christchurch was not known for urban art, even though it had been present, largely in more peripheral spaces and without fanfare, since the 1990s. Graffiti writing developed in Christchurch later than Aotearoa's other major urban centres Auckland and Wellington. There had long been 'graffiti' in Christchurch in the form of political slogans, peace signs, swastikas, gang logos, and declarations of affection or dissent, but the name-based, stylistic focus of hip hop graffiti writing took longer to catch on. Upon relocating in the early 2000 s, graffiti artist Pest 5 noted the difference between his Christchurch roots and his new home in Auckland: "In Christchurch my generation were the ones who set it. In Auckland my generation is three generations deep - you've got an old school and a super-duper old school. There's so much tradition and history." ${ }^{8}$ Christchurch's graffiti culture was small, responding to a distinct physical environment, and afflicted with the wider problem of artists leaving for more exciting pastures. ${ }^{9}$

Although relatively popular in Auckland and Wellington by the first decade of the new millennium (reflecting a growing global profile), street art was less prominent in Christchurch, lacking any artists with significant national profiles. ${ }^{10}$ While tagging, throw-ups and larger graffiti pieces were well established in the city, a smaller selection of post-graffiti tactics, such as paste-ups, stencils and other forms of urban painting were evident. ${ }^{11}$ While there was some social overlap between local graffiti and street artists, existing distinctions between the two remained. Lacking the more direct flow of influence and mentorship that is embedded within graffiti's crew-based culture, street artists shared a less defined sense of community. ${ }^{12}$ Given street art's popularity with younger artists (aided by digital dissemination) and the number of visual arts institutions in Christchurch, the presence of fewer post-graffiti practices might be surprising. However, the more isolated location, defection to larger cities, and a lack of recognition by the city's art world, provide some explanation. In hindsight, this local history provided no suggestion that these marginalised, and often maligned forms would become revealing cultural contributions to the altered, almost unrecognisable post-quake city.

In the wake of the earthquakes the city became a setting of opportunity for intrepid artists. Graffiti writers were afforded new found visibility and spaces to occupy. Street artists found stimulation in the transformed terrain. New contributors, compelled by the prevailing atmosphere to leave their imprint, drew on the profile and tactics of urban art for inspiration. As a result, urban art's once peripheral profile became a visible element of the recovering landscape, and much like the literal fall of the bronze statue of Robert Godley in Cathedral Square had symbolically reflected a potential rupture to the city's colonial identity. The rise of graffiti and street art, amongst other approaches, suggested a range of new thinking around city-building. ${ }^{13}$ 
American art writer Carlo McCormick has noted how graffiti and street art reflect our shifting relationship to the urban experience, suggesting that we must understand the city as a muse in order to contextualise the responses it encourages. McCormick asserts that:

Surely the rise of graffiti as a rigorous creative practice and codified language in the post-war era -when cities were subject to failing infrastructures, white flight, and major socioeconomic shifts downward as the suburbs became a new middle-class ideal- is no mere coincidence. Although it was widely regarded as part of the greater blight, looking back we can see how the more aesthetically ambitious graffiti might be seen, perhaps, as a reflexive beautification project. ${ }^{14}$

Through McCormick's suggestion, one can view the post-quake setting as the physical and conceptual muse for the creation and reception of the graffiti and street art that has appeared across the city's changing terrain. The editors of Christchurch: The Transitional City, Pt. IV noted that the scale of change, with over one thousand central city buildings eventually demolished, rendered post-quake central Christchurch "deeply disorientating". ${ }^{5}$ A confusing environment overloaded with unavoidable signs of the quakes' impact, from the large military-patrolled cordon erected in the immediate wake of the February quake, to the missing or visibly damaged buildings, ubiquitous road cones, kilometres of hurricane fencing and abundant ordinance signs, Christchurch provided an inviting array of spatial, social and commercial relationships for graffiti and street artists to investigate, explore, populate, transform and manipulate. In doing so, urban art in post-quake Christchurch might be viewed as a microcosm of the global contemporary complexities of the field, highlighting the various ways artists can engage with specific urban terrains, as well as the complicated relationships evident in the simultaneous existence of subversive guerrilla interventions and commissioned projects that serve as cultural capital.

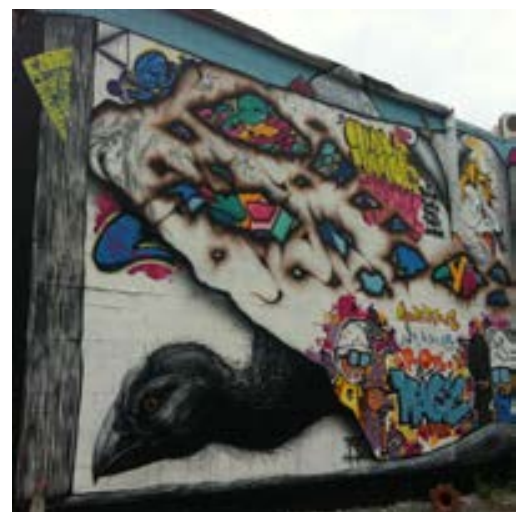

Figure 1. Wongi Wilson and Ikarus, with ROA, Jacob Yikes, Jungle, Sofles, Askew Allackbook Wall (Detail), Colombo Street, 2013

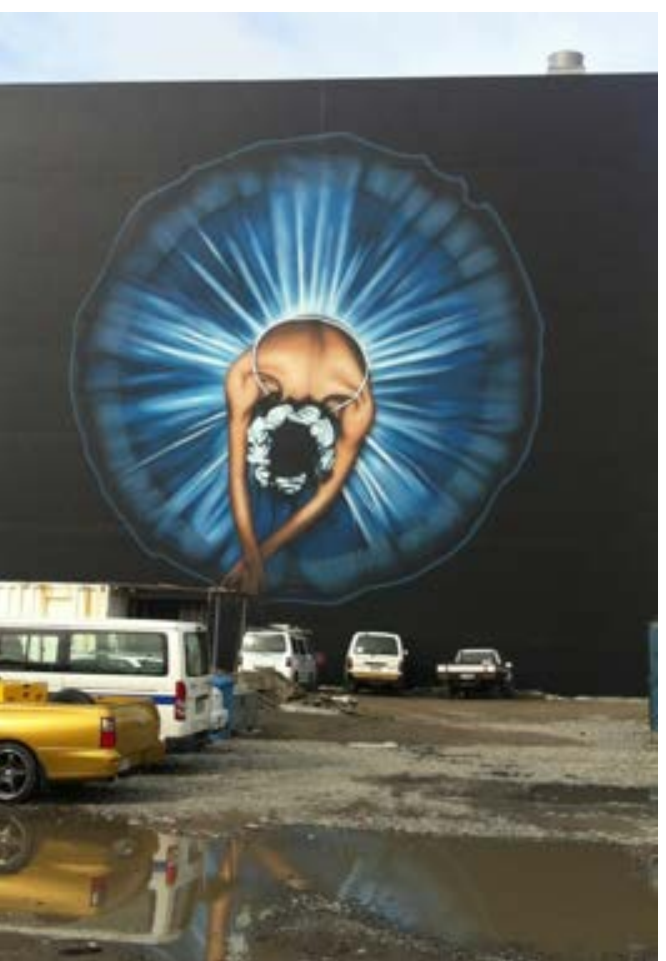

Figure 3. Owen Dippie, Armagh Street, 2013

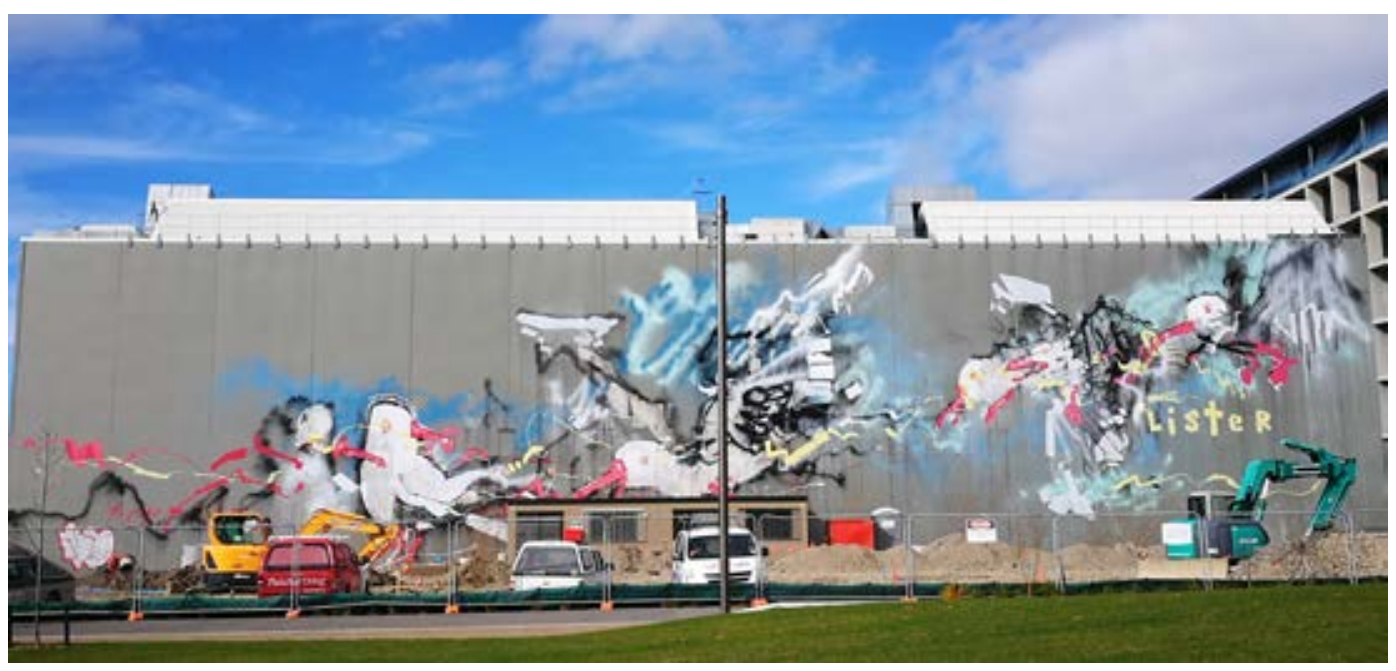

Figure 2. Anthony Lister, Cashel Street, 2013 


\section{TRANSFORMATION, DISTRACTION AND MARKING PLACE}

Impressive large-scale murals have been the most prominent expression of Christchurch's post-quake affection for urban art, transforming the abundant vacant walls with an array of images by artists from around Aotearoa and the world. Yet, they present only a partial view of the performances of graffiti and street art in the post-quake city. Murals, produced both independently and as part of events such as From the Ground Up (2013), Rise (2013), Spectrum (2014 and 2016) and most recently Street Prints Ōtautahi (2017), have told an array of stories, both distracting from and creating juxtapositions with the surrounding environment throughout the drawn-out rebuild. Reflecting contemporary muralism's urban art lineage, the murals combine acts of beautification with subtle echoes of rebellion, in imagery, such as a collective graffiti 'blackbook' co-ordinated by local artists Wongi Wilson and Ikarus (Figure 1), as well as process, as in Anthony Lister's use of fire extinguishers filled with paint in his energetic seagull mural (Figure 2). Yet, they also represent the emergence of a new arm of urban art, as a sanctioned and supported form of public art, one that has an uneasy relationship with the subversive roots of graffiti and street art, bound by the contract of commission or permission. Ultimately, while they inherently represent different concerns from guerrilla interventions, murals still present a range of ideas to consider, especially within the post-quake terrain.

Outside of their transformative potential, murals also suggest a practicality in their scale and prominence. Owen Dippie's largerthan-life ballerina, on the rear of the Isaac Theatre Royal, was originally produced overlooking an all-too-familiar gravelly vacant lot (Figure 3). Dippie explained that the fallen dancer was about to rise: "[l]t's symbolic of the city because like the ballerina, the city has fallen and is about to rise into something beautiful." 16 The massive ballerina, visible from distance, importantly provided a distraction from the ubiquitous presence of cranes and almost interchangeable partially-demolished buildings and empty lots that dominated the setting, taking on the status of a marker of place. The erosion of familiar surroundings and altered routes of travel left the city a difficult place to navigate. The dancer became a landmark anchored to a specific place, a defining occupant by which a distinct part of the city could be recognised, and other locations placed comparatively. Geographers Leslie King and Reginald Golledge describe landmarks by their ability to aid the navigation of a city, as "the physical elements of the city that people use as reference points. ${ }^{\prime 17}$ In post-quake central Christchurch, the clearing of the built environment necessitated the creation and recognition of new landmarks, and Dippie's ballerina, alongside other large-scale murals, such as Australian artist Numskull's I Always Knew You Would Come Back on Colombo Street, have served as such, even if they are ultimately temporary and constantly re-framed by the city's changing make-up (Figure 4). 


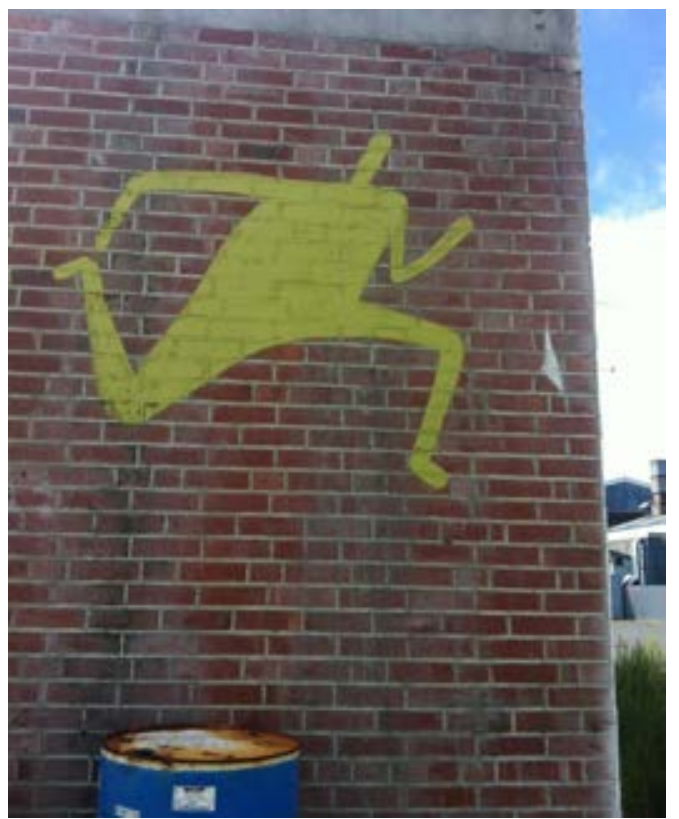

\section{EXPLORATION}

Alongside the transformative place-making performance of larger murals, smaller and often uninvited graffiti and street art interventions across the city suggested a mobility and sense of exploration suited to the transitional landscape. These highly ephemeral forms are less concerned with marking specific places, and to adapt a phrase by McCormick, might be considered not as landmarks, but as "remarks".18 These intimate interventions suggest and encourage exploration and investigation as a way of acknowledging the changed appearance and altered use of spaces, rather than purposeful navigation between places or by attempting to re-shape the landscape. They have engaged with the fractured mobility in the city, suggesting transgression and freedom of movement in a highly regulated, if still chaotic, setting. The invitation to explore the city's varied spaces and changing nature was evident in running shadow-like characters attributed to Drypnz (Figure 5). The faceless, silhouetted figures moved across the city like shadows caught mid-bound. They suggested the artist's mobility due to their repetition, but also invited the viewer to follow their intrepid lead as they traversed both the populated and the more peripheral spaces of the city.

\section{PRESENCE AND RE-POPULATING THE CITY}

Intimately tied to exploration, graffiti and street artists also performed an important role in re-populating the post-quake city, harnessing the declarative statement of presence inherent in urban art. While official events attempted to bring people back to the central city through welcoming and engaging public activities, graffiti and street art have represented an alternative, unofficial returning presence. Not only providing a presence through the representation of figures and faces, but also providing ephemeral traces of the presence of artists across the city. The occupation of spaces signified by the trace left behind was not just evident in de-facto characters, but also in written names, messages and questions.

If the fluorescent markings that covered the buildings checked by rescue teams signified the clearance of the city following the February quake, the last 'official' presence inside many of the damaged buildings before the red zone cordon was erected, the emerging presence of graffiti writing across the city suggested a returning presence, occupying empty buildings, rooftops and various spaces in between. Graffiti's use of names has always been related to the assertion of presence, and Christchurch's central city has proven an interesting, attractive and opportune site for writers to explore and leave their trace on the exposed walls and empty buildings. ${ }^{19}$ Collectively, the cacophony of names serves as an ongoing urban discussion; some making their point through impressive size or style, others through persistent repetition.

Similarly, the numerous faces, figures, animals, and creatures created by urban artists have provided a presence through their own life, actions and personalities, themselves actors in the experience of the inner city. The expressions and poses of these characters allowed people to engage with them personally, giving life to inanimate creations by constructing stories for their existence. Personalities ranged from menacing to mysterious, joyous to disinterested and stone-faced. Some were preoccupied with the surrounding landscape, others seeking the direct attention of passers-by, from the razor-like fangs of a large, green, amorphous creature suggesting a lurking sense of horror in damaged spaces, to a tiny giraffe grazing on a sprouting weed against a concrete wall. The changing appearance of the roving figure of Dr Suits, whose varied attire and facial hair between each appearance matched the changing state of the city, provided a combination of populating presence and inquisitive exploration. 
Something of a modern day flâneur observing the city, rarely seen without a bow-tie and dress suit, his sartorial elegance a stark provided a stark contrast to the city's unofficial uniform of fluorescent vests and hard hats (Figure 6).

If these characters provided a figurative population of the central city, and graffiti monikers were a direct reference to occupation, the suggestion of presence was also evident in the visible text of messages, jokes and questions plastered on walls and urban fixtures. These text-based interventions, like an analogue social media, created an open, informal, reflective and mysterious exchange between artist and unsuspecting, often unexpecting audience. Contrasting with the official flow of information, these snippets of dialogue did not intend to control, but instead seemingly reflected the alienation often felt in the congestion of modern cities, a feeling exacerbated in post-quake Christchurch despite the pervasive emptiness. On the fringe of the central city, stencilled in white paint on a buckled footpath, a piece of prose referenced the impact of the change upon the city and its residents (Figure 7). The unexpected text provided a moment of reflection for any viewer who literally stumbled upon it, connecting the experience of the inner city's changing physical landscape with a social impact:

On Peterborough Street the houses are wonky. The ground has been pulled out from underneath them. The trick worked and the houses stayed up, but they are wonky. If you lived in them you might become wonky too.

Intimate and informal conversations such as this, through their anonymous authorship, ask the viewer to contextualise the narrative within their experience of the surrounding, and as Waclawek suggests, "in the present moment". ${ }^{20}$ Notably, in post-quake Christchurch, with change occurring quickly, the present moment also necessarily involved the past and future as the surroundings were entrenched in both deconstruction and reconstruction.
Figure 6. Dr Suits, St Asaph Stra
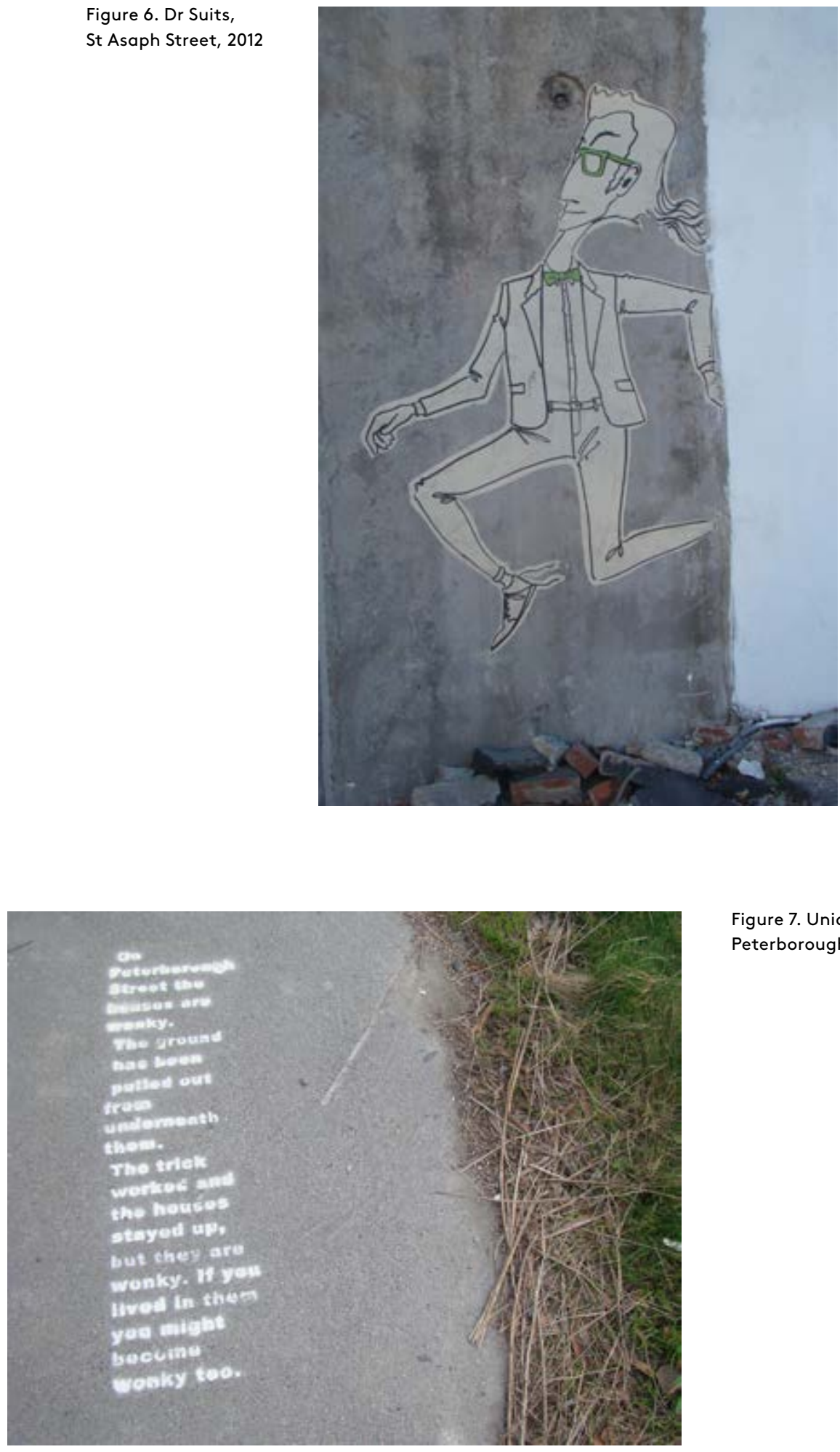


\section{RESPONDING TO CHANGE}

While exploring and populating the city, urban artists also directly responded to a terrain that provided numerous potential discourses, including the opportunity to echo and critique the practical rebuild in ways distinct from the official decision makers, planners and designers. Some artists saw the city itself as a victim of the earthquakes, a wounded body in need of care. This personification was exemplified by the over-sized sticking plasters pasted on damaged buildings across the central city (Figure 8 ). The plasters, created and installed by guerrilla duo the Band-Aid Bandits, not only provided a knowingly futile attempt at healing, but also offers of comfort in accompanying speech-bubbled phrases such as 'I'll kiss it better'. Art writer Justin Paton noted the resonance of the symbolic gesture as both reassuring and uncertain:

Transferring that gesture to a broken public wall is both tender and bitterly ironic. On one hand, it feels like an expression of genuine care, with the artist as a kind of urban physician, doctoring to the city's wounded spaces. But you can also see it as an expression of anxiety and frustration, as if the artist is wondering, in the face of all this damage, what anyone can actually do. ${ }^{21}$

The act of care represented by the plasters did extend a sense of humanity and expressed the importance of the recovery of the built environment for the city's collective well-being, while maintaining a playful sense of humour alongside the touching underlying sentiment. While the plasters represented an attempt at healing and therefore recovery, an additional discussion throughout post-quake Christchurch surrounded memorialising the event, and the role of memory in the experience of the city, both concepts urban artists have explored in varied ways.

\section{MEMORIALISATION AND MEMORY}

Exploring the concept of memorialisation and the role of memory in the experience of the city, artists undertook a variety of approaches. Still rattling with slowly diminishing aftershocks, damage more prominent than signs of renewal, the "...catharsis and 'closure'" of official

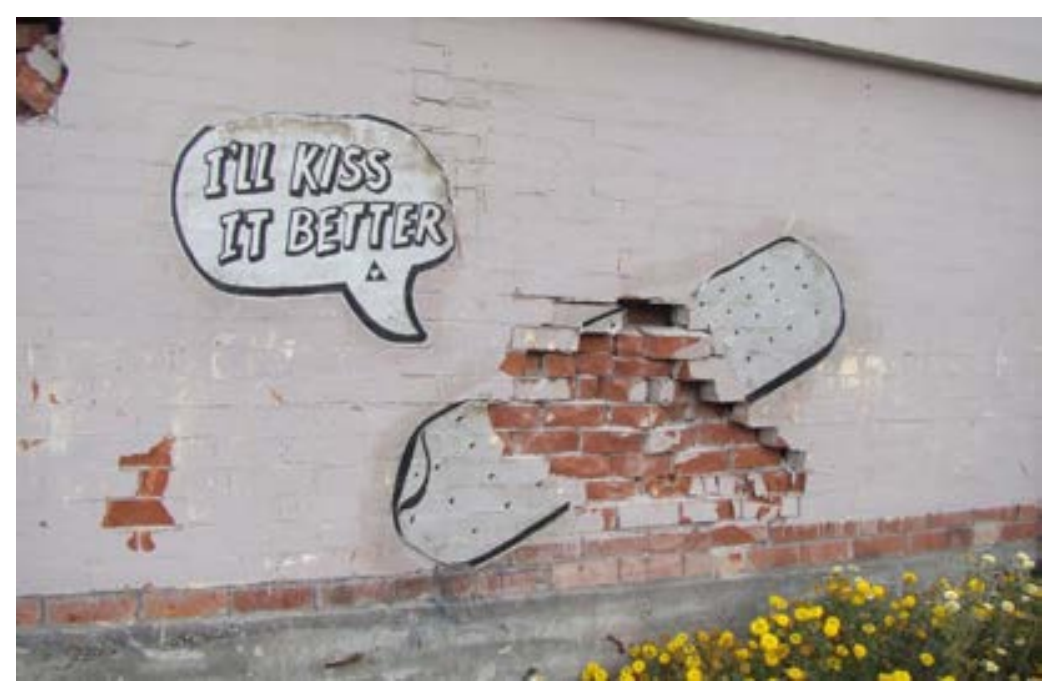

monuments made little sense in Christchurch's more immediate postquake environment. However, urban artists provided small, unofficial gestures of memorialisation. ${ }^{22}$ While grand memorial monuments suggest finality, they also potentially remove the burden of active remembrance from a public audience. James Young has discussed the role of memory in the creation of monuments in the contemporary setting, drawing on Pierre Nora to suggest that instead of embodying memory, monuments may in fact displace memory and supplant the need to actively remember:

For once we assign monumental form to memory, we have to some degree divested ourselves of the obligation to remember. In shouldering the memory-work, monuments may relieve viewers of their memory-burden. ${ }^{23}$

Memorials in this sense are detached from daily experience, accessible at convenience rather than providing a constant source of reflection, allowing us to forget when not obligated by some civic commemoration. ${ }^{24}$ In Christchurch, urban art's informal acts of remembrance and ability to trigger reflection through unexpected engagement, encouraged a more active consideration.

Graffiti artists produced murals that dealt directly with the earthquake experience, acting as gestures of remembrance and memorialisation, yet still imbued with a sense of ephemerality that 
a more official monument would inevitably lack. Graffiti artists have a long tradition of producing memorial murals that have honoured figures and events, from deceased graffiti writers and cultural pioneers to people from local and wider communities, often combining letterform traditions with figurative work. ${ }^{25}$ Explicit examples were found in the central city, Sydenham and Riccarton, and further afield in Rolleston (Figure 9). Imagery included a rising phoenix bird above crumbling stone graffiti pieces, depictions of USAR rescue crews, the shattered cathedral, and a memorial wreath, combining both explicit statements of memorialisation and suggested sentiments. While these memorial paintings served a noble purpose in the transitional cityscape, they were also aware of their role as temporary acknowledgements rather than final statements, fitting for the still changing landscape: aerosol paint fades, walls will be painted over, and cities will change. Amongst these more overt memorials, a range of other interventions engaged with the post-quake landscape in more subtle ways, triggering memories and associations of place. At the edge of Cranmer Square, additions to a damaged heritage building presented a combination of personal and open associations, while performing a type of memorialisation. Mike Hewson's Homage to Lost Spaces reflected on the quakes' impact on memories of place (Figure 10). Hewson's intervention was a public expression of the personal experience of losing meaningful places, places which poet Jeffrey Paparoa Holman declared as "our external memory banks" but also sites of our "internal geography". ${ }^{26}$ In April 2012, the boarded windows of the vacated 'Old Normal School' building in Cranmer

Square were anonymously adorned with large photographs of various figures; in a shattered doorway a figure in a hard hat and hi-vis vest talked on a mobile phone, in another window a figure leapt over a desk. The images brought the doomed building to life, as if exposing new activity within its walls. The pictures were taken from Hewson's time working in a shared studio in the Government Life Building near Cathedral Square, itself doomed to demolition. As such they served as personal memories of a cherished time and place, abruptly interrupted by the earthquakes. While Hewson was celebrating a specific aspect of his own experience, the placement of the works on the exterior of a building with a layered history, both briefly rejuvenated the Normal School before its eventual demolition, and allowed the audience to draw their personal associations with the site through the reactivation. The unexplained nature of the images meant they could evoke some personal memory of the building itself, conjured up by the breath of life

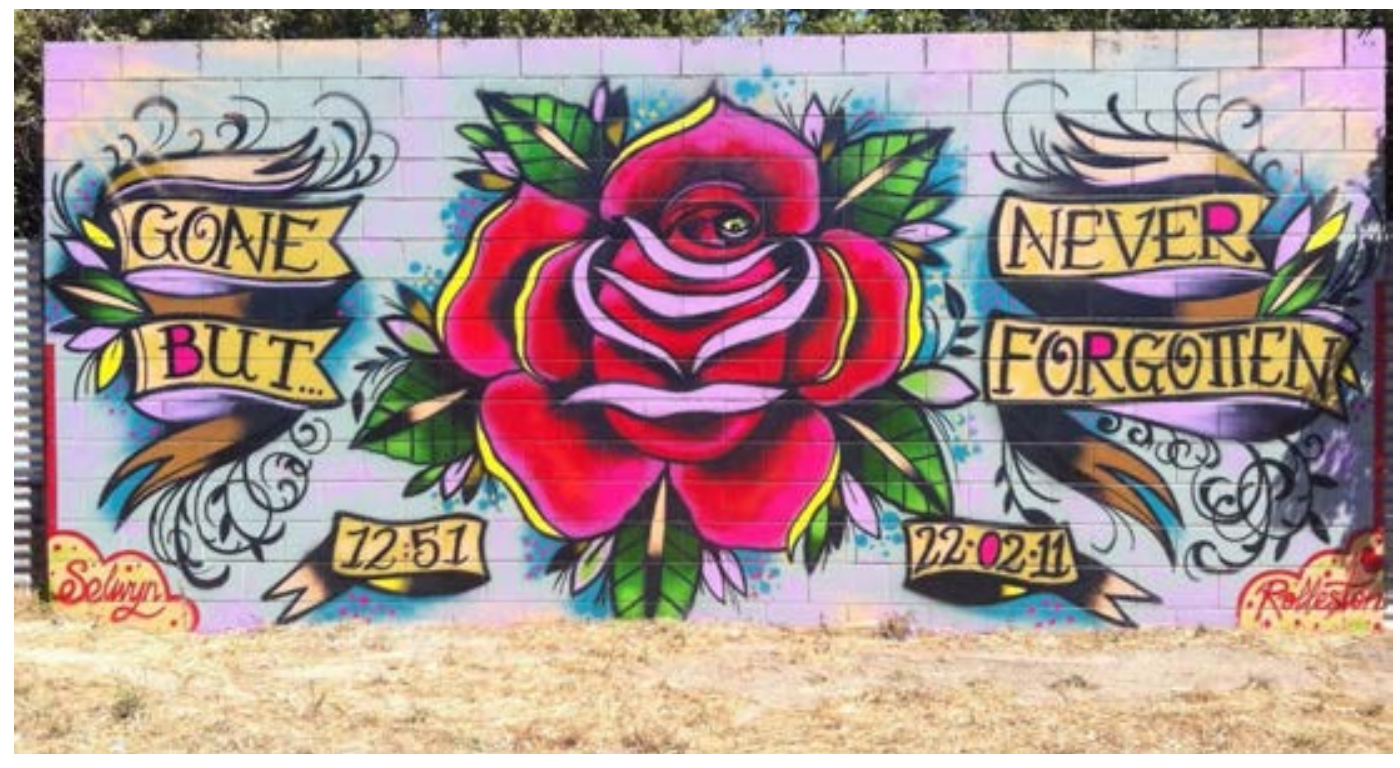

Figure 9. Unidentified artist, Gone But Never Forgotten, Rolleston, c.2013

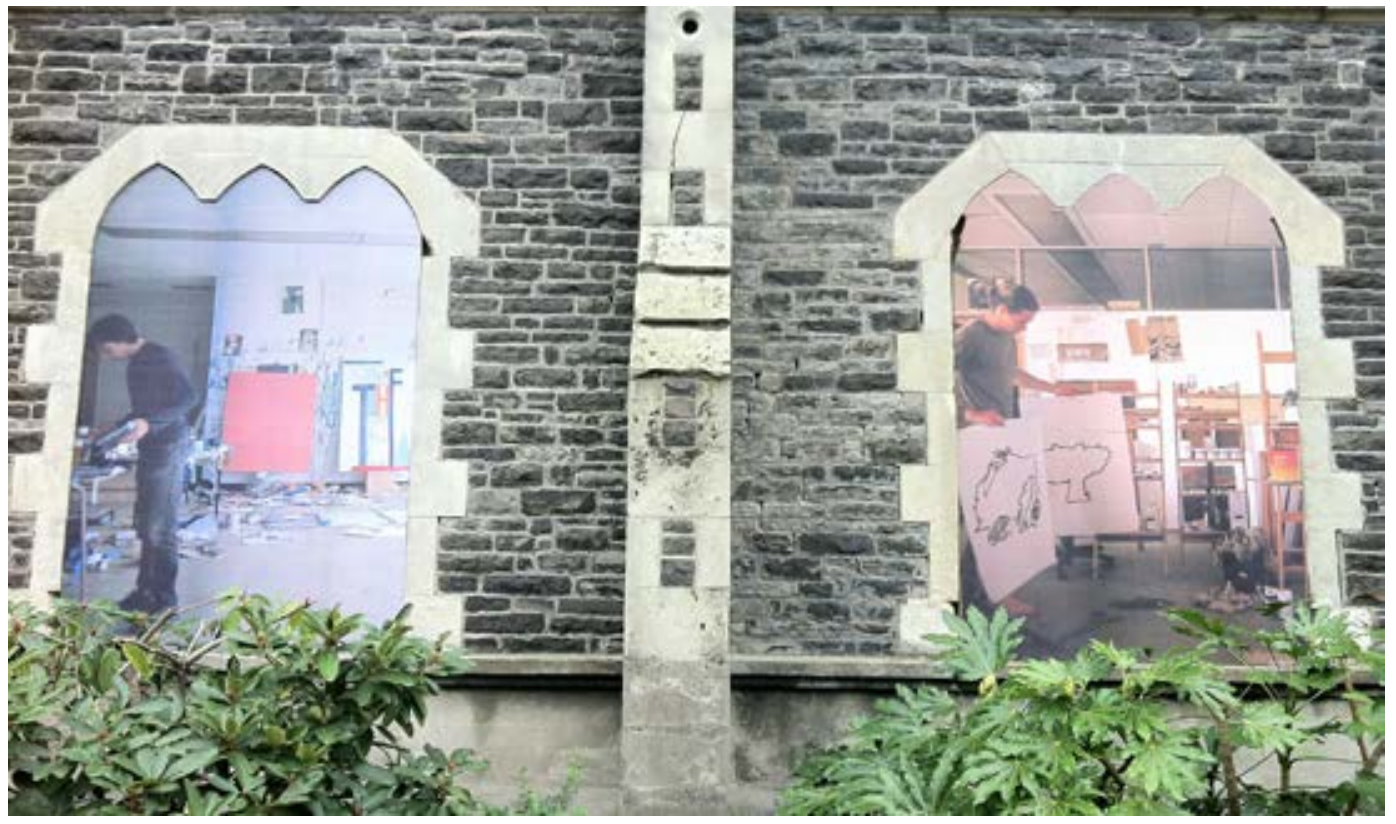

Figure 10. Mike Hewson, Homag to Lost Spaces (detail), Cranmer Square, 2012 
given by their presence. ${ }^{27}$ Hewson's interventions signified the ability of the unexpected additions to operate on multiple levels, to expose the impact of the quakes on the surrounding city and the meaningfu connections people had made over time, through the encounter rather than providing an explicit narrative of memorialisation.

\section{CRITIQUING CHANGE}

In addition to reflecting on the emotional impact of deconstructing a city, the inevitable reconstruction allowed urban artists, and citizens, to consider and critique the rebuild. Often a post-disaster environment will unearth the power relations at play in a city, leaving people to question and challenge the perceptions of inequality and the process of recovery. Rebecca Solnit has argued that authority will often fear the potential of disasters to undermine their control:

[A] power struggle often takes place in disaster- and real political and social change can result, from that struggle, or from the new sense of self and society that emerges. ${ }^{28}$

Christchurch's post-quake experience, including the decision-making processes surrounding the rebuild, the status of heritage buildings and protracted insurance issues, has awakened in many people the desire to have their voice heard..$^{29}$ The use of public space as a site

for the dissemination of messages and images has been a common approach. Providing alternative public discourses, artists were able to criticise and often make fun of civic authorities and the control of the city. As Waclawek explains, regardless of the specific intent, making art in the streets without permission provides a form of "resistance to sanctioned imagery and the notion of public space", and in post-quake Christchurch, this approach afforded the opportunity to expose the complex relationships at play in rebuilding a city. ${ }^{30}$

While some examples avoided specific references, such as a remixed ordinance sign applied to a wall reading 'WAKE UP', seemingly a comment around the numbing effects of the cacophony of signs that signalled the highly controlled environment, others targeted political figures (Figure 11). Spread throughout the city, street artist Cubey pasted drawings of Canterbury Earthquake Recovery Authority (CERA) head Roger Sutton, Central City Development Unit (CCDU) director

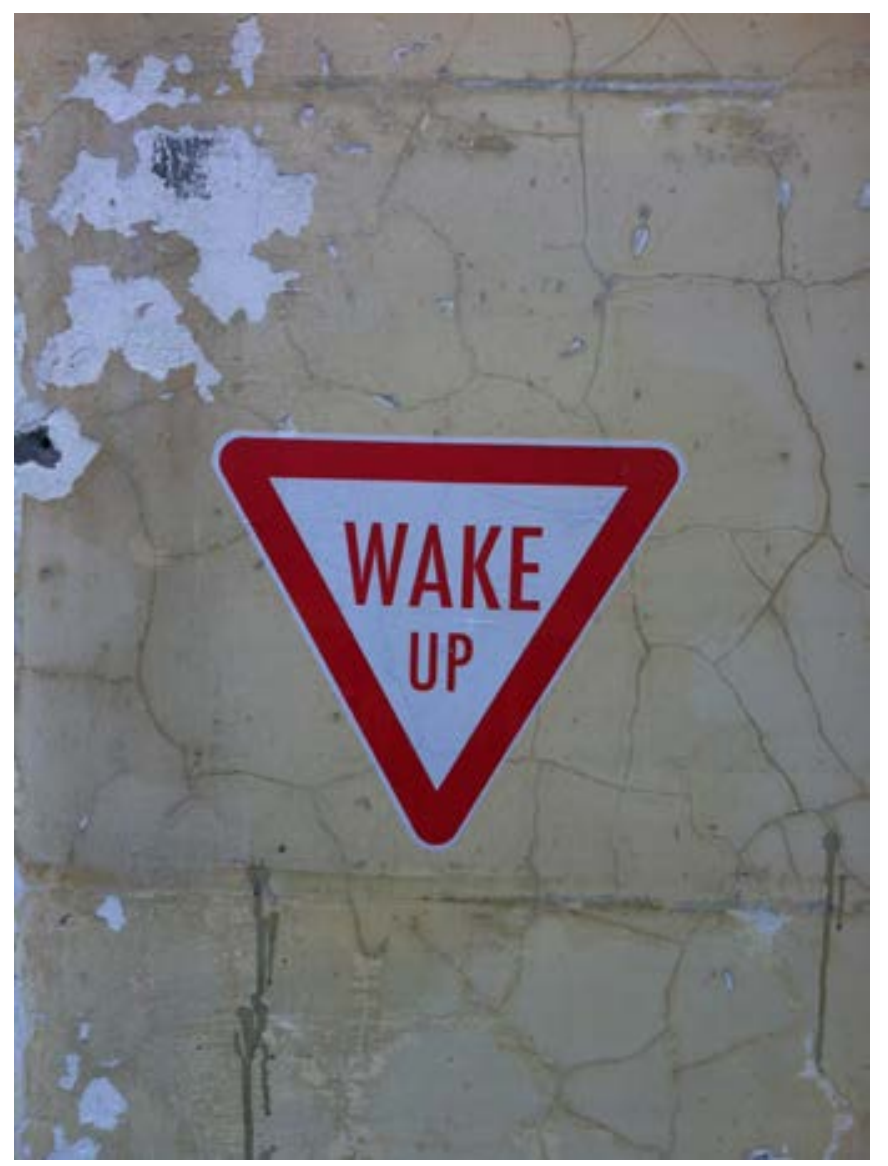

Figure 12. Cubey, Thre Wise Men, central Christchurch, 2012

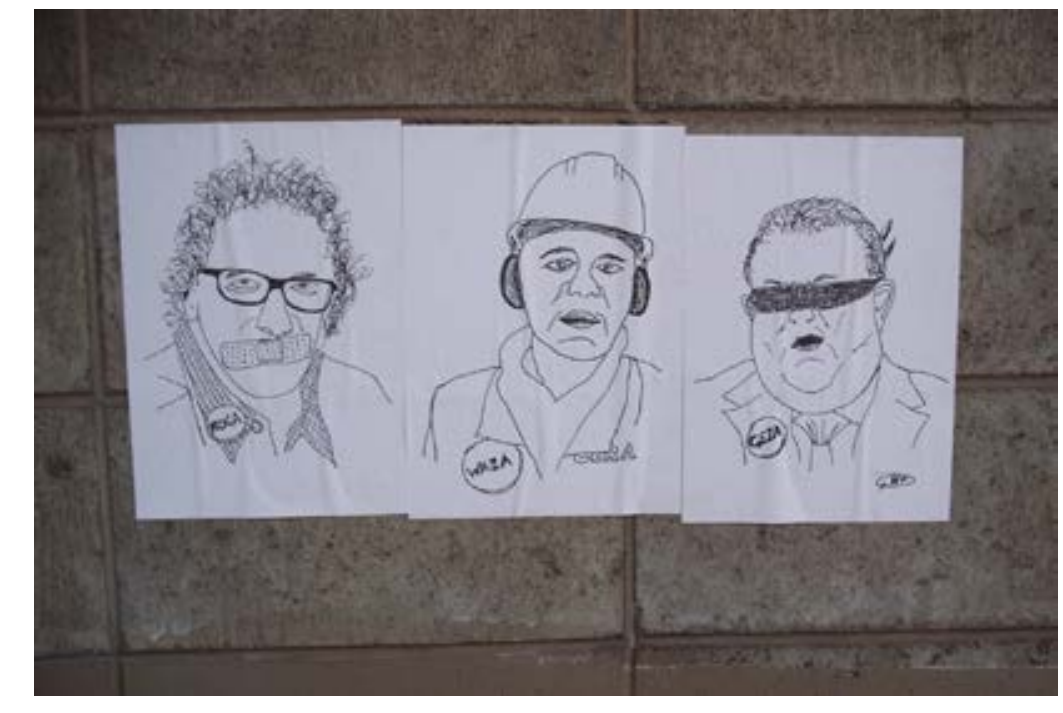


Warwick Isaacs and Earthquake Recovery Minister Gerry Brownlee, three of the most influential figures in post-quake Christchurch. Identified as "Roga, Waza and Geza", Sutton's mouth was covered by a sticking plaster, Isaac's hearing blocked by construction-site ear muffs, and Brownlee's vision obscured by a blindfold, the "Three Wise Men" were rendered as seeing, hearing, and speaking no truth (Figure 12) ${ }^{31}$ Avoiding the potential censorship of commissioned projects, such commentaries provided pointed visual messages of frustration around the handling of the recovery. Notably, even interventions that were not overtly political in their content or message, when created without permission, automatically entered the discussion of the power structures of the recovery, existing and operating outside of the official process of the rebuild.

\section{CONCLUSION}

The continued prominence of urban art in Christchurch is uncertain. Unsanctioned interventions now find fewer spots to occupy as commercial activity has returned. Murals continue to mark the built environment as symbols of the recovery, but they also disappear as the cityscape evolves. The offering of contemporary muralism as definitive of 'street art' raises interesting questions about the control and complex evolving make-up of urban art, a wide-spread discussion not exclusive to Christchurch. However, the post-quake landscape has offered a vital contextual setting for reading the varied performances of graffiti and street art, illustrating the transferrable abilities of these forms, not just as urban patina, but as vehicles that can respond to specific environments. Urban artists' ability to engage with ideas involving transformation, place-making, exploration, presence, memory and the critique of authority, has ensured that their interventions have been meaningful additions to the transitional city, often in very different ways from other forms of public art and official flows of information. The question now remains, has the recognition of these abilities been enough to ensure that urban art remains a part of the city's creative fabric, even without such a specific lens?

\section{REFERENCES}

Alexanrakis, Othon. "Indirect Activism: Graffiti and Political Possibility in Athens, Greece", Cultural Anthropology 31, no. 2 (2016): 272-296.

Ansley, Bruce. Christchurch Heritage: A Celebration of Lost Buildings \& Streetscapes. Auckland: Random House, 2011.

Bennett, Barnaby, Eugenio Boidi and Irene Boles (eds.). Christchurch: The Transitional City, Pt. IV. Christchurch: Freerange Press, 2012.

Bennett, Barnaby, James Dann, Emma Johnson and Ryan Reynolds (eds.). Once in a Lifetime:

City-building after Disaster in Christchurch.

Christchurch: Freerange Press, 2014

Gastman, Roger and Caleb Neelon. The History of American Graffiti. New York: Harper Design, 2010.

Gröndahl, Mia. Gaza Graffiti: Messages of Love and Politics, Cairo/New York: The American University in Cairo Press, 2009.

Lewisohn, Cedar. Street Art - The Graffiti Revolution. London: Tate Publishing, 2008.

McCormick, Carlo. "The Writing on the Wall", in Jeffrey Deitch (ed.), Art in the Streets, (New York: MoCA/Skira Rizzoli, 2011): 19-25.

O'Donnell, Elliot. InForm: New Zealand Graffiti Artists Discuss Their Work. Auckland: Reed Publishing, 2007.

\section{ENDNOTES}

1 Significant earthquakes struck in September 2010 and February 2011. The February earthquake resulted in 186 deaths, and widespread physical damage, especially in the central city (Chris Moore, with Press Widespread physical dame, with Press d Fairfox photographers, picture research by Jude Tewnion, Earthquake: Christchurch, New Zealand 22 February 2011, Auckland, Random House, 2011). Christchurch's inclusion in Lonely Planet's 2017 Street Art guide (Ed Bartlett, ed., Ireland, Lonely Planet Global Limited, 2017) signified the city's new-found 'destination' status.

2 The performances of street culture in post-Katrina New Orleans are discussed in
Parry, William. Against the Wall: The Art of Resistance in Palestine London/Chicago: Lawrence Hill Books, 2010.

Schacter, Rafael. The World Atlas of Street Art and Graffiti. Sydney: Newsouth Publishers, 2013.

Seno, Ethel (ed.), with Carlo McCormick, Marc \& Sara Schiller. Trespass: A History of Uncommissioned Urban Art. Köln: Taschen, 2010.

Solnit, Rebecca. A Paradise Built in Hell - The Extraordinary Communities that Arise in Disaster. London: Penguin, 2010.

Stone, Don and Basma Hamdy. Walls of Freedom: Street Art of the Egyptian Revolution: Germany: From Here to Fame, 2014

Taylor, Helen. "After the Deluge: The Post-Katrina Cultural Revival of New Orleans", Journal of American Studies 44, no. 3 (2010): 483-501.

Turner, Richard Brent. Jazz Religion, the Second Line, and Black New Orleans. Bloomington: Indiana University Press, 2009.

Waclawek, Anna. Graffiti and Street Art. London: Thames \& Hudson, 2011. numerous studies (Helen Taylor, 'After the Deluge: The Post-Katrina Cultural Revival of New Orleans', Journal of American Studies, vol. 44/no. 3, 2010, pp. 483-501; Richard Brent Turner, Jazz Religion, the Second Line, and Black New Orleans, Bloomington, Indiana University Press, 2009). A range of new approaches to public space in Christchurch have been explored in Christchurch: Th Transitional City, Pt. IV (eds. Barnaby Bennett, Eugenio Boidi and Irene Boles, Christchurch, Freerange Press, 2012) and Once in a Lifetime: City-building after Disaster in Christchurch (eds. Bennett, James Dann, Emma Johnson and Ryan Reynolds, Christchurch, Freerange Press, 2014). 
3 Schacter, The World Atlas of Street Art and Graffiti, Sydney, Newsouth Publishers, 2013; Waclawek, Graffiti and Street Art, London, Thames \& Hudson, 2011; Lewisohn, Street Art - The Graffiti Revolution, London, Tate Publishing, 2008

4 Waclawek, p. 29.

5 Waclawek uses the term urban art interchangeably at times in Graffiti and Street Art (2011, p. 9.)

6 Although studies around various cultural and artistic responses to post-disaster environments have informed this study, the primary influence has been urban art scholarship, which is where this work seeks to be placed.

7 Don Stone and Basma Hamdy, Walls of Freedom: Street Art of the Egyptian Revolution, Germany, From Here to Fame, 2014; Mia Gröndahl, Gaza Graffiti: Messages of Love and Politics, Cairo/New York, The American University in Cairo Press, 2009; William Parry, Against the Wall: The Art of Resistance in Palestine, London/Chicago, Lawrence Hill Books, 2010; Othon Alexanrakis, 'Indirect Activism: Graffiti and Political Possibility in Athens, Greece', Cultural Anthropology, vol. 31/no. 2, 2016, pp. 272-296. In New Zealand, towns and cities such as Dunedin, Hamilton, Tauranga, Napier an Mount Maunganui have all utilised urban art and mural festivals as tools of cultural identity building, establishing festivals and mural programs in recent years.

8 Elliot O'Donnell, InForm: New Zealand Graffiti Artists Discuss Their Work, Auckland Reed Publishing (NZ) Ltd, 2007, p. 123.

9 Uncredited, 'Ikarus and Dcypher', Disrupt Magazine, number 6, 2005, p. 86.

10 This is exemplified by the lack of any Christchurch artists in the New Zealand 'street art documentary' Dregs (dir. and prod. Karl Sheridan and Cinzah Merkens, Dregs Ltd, 2012

11 Graffiti culture includes a hierarchy of single line 'tags', single colour-filled and outlined 'throw-ups', and more developed and detailed 'masterpieces'. 'Paste-ups' refer to posters applied to walls with a traditionally homemade adhesive.

12 Waclawek, p. 26.
13 Bruce Ansley, Christchurch Heritage: A Celebration of Lost Buildings \& Streetscapes, Auckland, Random House, 2011, p. 9.

14 Carlo McCormick, 'The Writing on the Wall', in Jeffrey Deitch, ed., Art in the Streets, New York, MoCA/Skira Rizzoli, 2011, pp. 19-25.

15 Bennett, Boidi, Boles, eds., Christchurch The Transitional City Pt IV, p. 4.; Georgina Stylianou, 'Demolitions draw to end', The Press, Monday, September 9, 2013, p. A3.

16 Eddie Zammit, "Owen Dippie: Profile", No Cure Magazine, Issue 9, 2015, p. 33.

17 Leslie King and Reginald Golledge, Cities, Space, and Behaviour: The Elements of Urban Geography. New Jersey, Prentice-Hall, Inc. 1978 , p. 242

18 Ethel Seno, ed., with Carlo McCormick Marc \& Sara Schiller, Trespass: A History of Uncommissioned Urban Art, Köln, Taschen, 2010, p. 83.

19 Roger Gastman and Caleb Neelon, The History of American Graffiti, New York, Harper Design, 2010, p.31.

20 Waclawek, pp. 102-104.

21 Justin Paton, "Perimeter Notes: A Day Around the Red Zone", Bulletin - Christchurch Art Gallery Te Puna o Waiwhetu, B.167, Autumn, March-May, 2012, p. 19

22 Justin Paton, "Here and Gone", in Bulletin - Christchurch City Art Gallery Te Puna Waiwhetu, B.166, Summer, December 2011-February 2012, p. 32.

23 James E. Young, 'The Counter-Monument: Memory against itself in Germany Today', in WJT Mitchell, ed., Art \& The Public Sphere, Chicago, Chicago University Press, 1992, p. 55. 24 Ibid.

25 Joseph Sciorra and Martha Cooper, R.I.P.: New York Spraycan Memorials, London, Thames \& Hudson, 2002

26 Jeffrey Paparoa Holman, Shaken Down 6.3 - Poems from the second Christchurch earthquake, 22 February 2011, Christchurch, Canterbury University Press, 2012, p.50.

27 While watching passing traffic doubletake at Hewson's interventions, a strange approached and recounted music lessons inside the Normal School building, personal memories conjured by the images' activation of the building.
28 Rebecca Solnit, A Paradise Built in Hell - The Extraordinary Communities that Arise in

Disaster, London, Penguin, 2010, p. 21.

29 Bennett, Dann, Johnson and Reynolds, eds. Once in a Lifetime, p. 177

30 Waclawek, p. 73.

31 Bennett, Boidi and Boles, eds., p. 254. 